\title{
MANAJEMEN SEKOLAH ALAM DALAM PENGEMBANGAN KARAKTER PADA JENJANG SEKOLAH DASAR DI SCHOOL OF UNIVERSE
}

\author{
Elin Asrofah Qibtiah ${ }^{1}$, Rita Retnowati ${ }^{2}$, Griet Helena Laihad ${ }^{2}$ \\ ${ }^{1}$ Staf Mahkamah Konstitusi RI, Jakarta, DKI Jakarta \\ ${ }^{2}$ Program Pascasarjana Universitas Pakuan, \\ Email: pasca@unpak.ac.id
}

\begin{abstract}
Nature school is one of the new concepts of education. Students are taught how to use and keep the nature for life. As one example, schools that applies the concept of a nature school is School of Universe which integrates four curricula that comprises character, logic, leadership, and business curriculum. This research aims at analysing and describing the uniqueness or special characteristics of the processes and steps of nature school management in School of Universe, which is located in Parung-Bogor, in developing character, logic, leadership, and business curriculum in Elementary School level. Management of Nature School being studied covered the stages of planning, organizing, directing and implementation, and controlling. This research applied qualitative methods and focused on researcher as its instrument. The The data were collected from interview, observation, and documentation studies. Based on the existing data and information This thesis finds and concludes that good and structured process of planning, organizing, directing, and controlling becomes main supporting factor in developing character, logic, leadership, and business in elementary school level in the School of Universe. In order to achieve the goals as listed on the character, logic, leadership, and business curriculum, it needs detail and consistent planning, organization based on needs, direction and implementation that is in accordance with components of program which has been arranged and planned in advance, as well as regular intensive control using objective instruments that meet students' learning development.
\end{abstract}

Keywords: management, nature school, school management, character, logic, leadership, business.

\begin{abstract}
ABSTRAK
Sekolah alam merupakan salah satu konsep baru dalam pendidikan, dimana siswa diajarkan bagaimana memanfaatkan sekaligus menjaga alam untuk kehidupan. Sebagai contoh, sekolah yang menerapkan konsep sekolah alam adalah School of Universe yang mengintegrasikan empat kurikulum yang terdiri dari kurikulum akhlak, logika, kepemimpinan, dan bisnis. Penelitian ini bertujuan untuk mengkaji dan mendeskripsikan keunikan atau kekhasan proses dan tahapan dalam manajemen sekolah alam di School of Universe, yang terletak di ParungBogor, dalam mengembangkan kurikulum akhlak, logika, kepemimpinan, dan bisnis pada jenjang Sekolah Dasar. Manajemen sekolah alam yang dikaji meliputi tahapan perencanaan, pengorganisasian, pengarahan dan pelaksanaan, serta pengendalian. Penelitian ini menggunakan metode kualitatif, dengan peneliti sebagai instrumen. Teknik pengambilan data yang digunakan dengan wawancara, observasi, dan studi dokumentasi. Berdasarkan data dan informasi yang ada, diperoleh hasil dan dapat disimpulkan bahwa proses perencanaan, pengorganisasian, pengarahan, dan pengendalian yang baik dan terstruktur menjadi faktor penunjang utama dalam pengembangan akhlak, logika, kepemimpinan, dan bisnis pada
\end{abstract}


jenjang Sekolah Dasar di School of Universe. Untuk dapat mencapai tujuan sebagaimana tercantum dalam kurikulum akhlak, logika, kepemimpinan, dan bisnis maka diperlukan perencanaan yang detail dan ajeg, pengorganisasian yang sesuai dengan kebutuhan, pengarahan serta implementasi sesuai dengan komponen-komponen program yang telah disusun dan direncanakan, serta pengendalian yang intensif secara berkala dengan instrumen yang disusun secara objektif sesuai dengan kondisi perkembangan pembelajaran siswa.

Kata Kunci: manajemen, sekolah alam, manajemen sekolah, akhlak, logika, kepemimpinan, bisnis.

\section{PENDAHULUAN}

Hakekat pendidikan merupakan kebutuhan dari setiap individu manusia. Setiap individu perlu untuk mengembangkan diri melalui peningkatan pengetahuan dan pemahaman dalam berbagai aspek kehidupan. Peningkatan pengetahuan dan pemahaman inilah yang nanti akan berperan dalam peningkatan kompetensi individu untuk dapat meningkatkan daya saing dalam menghadapi tuntutan kehidupan masa depan. Salah satu cara peningkatan kompetensi tersebut ditempuh melalui proses pendidikan. Oleh karena itu pendidikan menjadi salah satu aspek penting dalam kehidupan manusia. Perkembangan pembangunan dan peningkatan kehidupan manusia pada dasarnya tidak dapat terpisah dari hubungan saling keterkaitan dengan alam dan lingkungan yang ada di sekitar. Saat ini, sebagaimana diketahui bersama telah banyak terjadi kerusakan alam dan lingkungan yang diakibatkan oleh tangan-tangan manusia. Kerusakan alam dan lingkungan ini menjadikan ketidakseimbangan dalam ekosistem.

Mengamati fenomena yang terjadi saat ini tersebut, menjadi suatu kebutuhan dan keharusan bagi manusia untuk dapat mengupayakan menciptakan kehidupan yang berkesinambungan dan selaras antara manusia dengan alam dan lingkungan. Upaya ini dapat diwujudkan dengan mengusahakan terwujudnya ekosistem yang layak huni dan berkesinambungan. Salah satu aspek yang dapat mendukung upaya ini adalah melalui pendidikan, termasuk pendidikan yang berlangsung di sekolah. Penyelenggaraan pendidikan memiliki peluang yang sangat luas untuk dapat memberi kesadaran bagi peserta didik dan masyarakat secara lebih luas untuk dapat kembali menjaga kelestarian alam dan lingkungan demi keberlangsungan hidup berkelanjutan yang sejahtera. Dengan adanya sumber daya manusia yang berkualitas dan dengan didukung kekuatan sumber daya alam, maka akan menghasilkan potensi luar biasa dalam pengembangan dan peningkatan taraf kehidupan manusia baik bagi diri sendiri maupun bagi lingkungan tempat menjalani kehidupan.

\section{Manajemen}

Manajemen terdiri atas sistem organisasi yang berhubungan dengan model dan pola keorganisasian serta sistem manajerial organisasi yang berkaitan dengan pola-pola pengorganisasian, kepemimpinan, dan kerjasama dalam organisasi. (Hikmat. 2014:11). Manajemen dalam tataran profesi berlandaskan kepada nilai-nilai etik organisasi, diperlukan sumber daya manusia dengan keahlian khusus untuk dalam menjalankan pekerjaan manajerial secara profesional (Chairunnisa, 2016:2). Brown (dalam Machali. 2016:2) menyebutkan bahwa manajemen merupakan suatu alat atau cara untuk memberdayakan sumber daya baik dalam bentuk orang, biaya, perlengkapan, bahan, dan metode yang ada pada suatu organisasi secara efektif untuk mencapai tujuan yang diinginkan. Manajemen adalah upaya yang di dalamnya mengandung proses perencanaan, pengorganisasian, kepemimpinan, dan pengendalian anggota organisasi yang diimbangi dengan pemberdayaan seluruh sumber daya organisasi secara efektif dan efisien untuk dapat mencapai tujuan yang 
telah ditetapkan (Stoner dalam Machali, 2016:3). Hal ini diperkuat oleh penjelasan yang dikemukakan oleh Machali (2016:4) yang menjabarkan bahwa inti manajemen adalah usaha untuk mengelola atau mengatur organisasi yang diarahkan untuk mencapai tujuan organisasi yang telah ditetapkan secara produktif, efektif, dan efisien.

Berdasarkan penjabaran tersebut, dapat ditarik sintesis bahawa manajemen merupakan suatu ilmu, konsep, dan cara pengelolaan organisasi dengan memanfaatkan secara produktif, efektif dan efisien seluruh sumber daya organisasi yang ada untuk mencapai tujuan dan hasil yang ingin dicapai. Pemanfaatan sumber daya organisasi ini perlu ditunjang dengan kemampuan dan keterampilan sumber daya manusia pengelolanya, sehingga kinerja organisasi dapat berjalan dengan produktif dalam upaya pencapaian tujuan-tujuan yang telah ditetapkan.

Fungsi Dasar Manajemen: Perencanaan (Planning), Pengorganisasian (Organizing), Pengarahan (Directing), Evaluasi (Evaluating) dan Pengendalian (Controlling)

\section{Manajemen Sekolah (School Management)}

Drucker (dalam Tatang, 2015:17) menyebutkan bahwa prinsip manajemen sekolah berdasarkan kepada sasaran yang menempatkan pimpinan sekolah dan stakeholders untuk bersama-sama merumuskan visi, misi, dan tujuan pendidikan yang diterapkan di sekolah. Sagala (dalam Nurochim, 2016:11) berpendapat bahwa manajemen sekolah atau manajemen pendidikan adalah penerapan ilmu manajemen dalam proses pembinaan, pengembangan, dan pengendalian usaha serta praktek-praktek pendidikan yang berlangsung di sekolah. Douglas (dalam Tatang, 2015:17) menyebutkan prinsip-prinsip manajemen sekolah terdiri atas: 1) memprioritaskan tujuan di atas kepentingan pribadi dan kepentingan mekanisme kerja; 2) mengkoordinasikan wewenang dan tanggung jawab; 3) memberikan tanggung jawab yang sesuai kepada anggota sekolah; 4) memahami dengan baik faktor psikologis anggota, dan 5) relativitas nilai-nilai di sekolah.

Nurochim (2016:17) menjelaskan bahwa manajemen sekolah adalah dimana sekumpulan sumber daya manusia yang ada di sekolah menjadi pelaksana berdasarkan pada pembagian tugas yang telah ditentukan dan saling bekerjasama untuk mencapai tujuan pendidikan dan tujuan sekolah yang diharapkan. Berdasarkan pemaparan tersebut, disintesis bahwa manajemen sekolah adalah penerapan konsep dan fungsi-fungsi manajemen ke dalam proses pengelolaan sekolah sesuai dengan tujuan yang ingin dicapai oleh sekolah. Manajemen sekolah ini dimaksudkan untuk dapat memenuhi kebutuhan stakeholder, sehingga seluruh proses dan tahapannya mulai dari perencanaan, pengorganisasian, pengarahan, dan pengendalian dimaksudkan untuk dapat menyesuaikan dengan harapan sekolah dan para stakeholder. Manajemen sekolah berkenaan dengan seluruh komponen pembelajaran di sekolah, mulai dari kurikulum, kesiswaan, hingga sarana dan prasarana yang keseluruhannya dikelola untuk memenuhi kebutuhan penyelenggaraan pendidikan di sekolah.

\section{Sekolah Alam}

Sekolah alam merupakan konsep sekolah yang unik dibandingkan dengan sekolah konvensional, dimana di dalam sekolah alam terdapat elemen visual, spasial, kinestetis, dan naturalis. Konsep sekolah ini mengedepankan alam sebagai sumber inspirasi bagi peserta didik yang diwujudkan dalam bentuk perancangan tempat belajar yang terintegrasi dengan ruang luar (Veronika, 2012:1). Maulana (2016:24) menyebutkan bahwa sekolah alam merupakan model sekolah yang memberikan peluang kepada peserta didik untuk dapat berkembang sesuai dengan potensinya tanpa dibatasi oleh kegiatan eksternal berupa pengaturan yang baku. Pengertian lebih luas diungkapkan Nasir (dalam Hadziq, 2016:24) yang berpendapat bahwa sekolah alam merupakan salah satu upaya penyelenggaraan sistem pendidikan yang secara komprehensif memadukan konsep keseimbangan antara nilai, sikap, 
pengetahuan, kecerdasan, keterampilan, kemampuan, komunikasi, serta kesadaran akan ekologi lingkungan. Heather (2014:12) bahwa sekolah alam adalah pendekatan dan program pendidikan yang menerapkan mulai dari sebagian waktu belajar hingga hampir seluruh waktu pembelajarannya dilakukan di luar ruangan kelas.

Hafiz (Maulana, 2016:24), bahwa sekolah alam adalah alternatif sekolah dengan berbasis alam dengan memanfaatkan alam sebagai media untuk menumbuhkan potensipotensi dan bakat peserta didik secara khusus. Mertins (2017:1-5) meyakini bahwa pendidikan berwawasan lingkungan yang berbasis alam dapat menciptakan pemikiran yang cemerlang. Berdasarkan beberapa penjabaran tersebut, maka dapat disintesis bahwa sekolah alam adalah sekolah berbasis alam yang memanfaatkan alam sebagai salah satu sumber belajar utama dan menggunakan pendekatan tematik dimana menggabungkan antara teori dengan pengamatan dan pengalaman praktek secara langsung di lapangan sehingga peserta didik dapat dengan bebas dan secara luas mengkonstruksi pemahaman belajarnya.

\section{Akhlak, Logika, Kepemimpinan, Dan Bisnis}

\section{Akhlak}

Akhlak diartikan sebagai kehendak yang dibiasakan dan sifat yang melekat dan tertanam kuat dalam jiwa yang terlihat dalam bentuk perbuatan lahiriah yang didorong oleh suatu keinginan secara sadar tanpa memerlukan pertimbangan terlebih dahulu yang pada akhirnya menjadi kebiasaan dan kepribadian seorang individu (Rasyad, 2015:91-92). Habibah (2015:73) menyebutkan bahwa akhlak merupakan suatu pola tingkah laku yang mengakumulasikan antara aspek keyakinan dengan ketaatan yang pada akhirnya menggambarkan perilaku yang baik. Sejalan dengan pendapat sebelumnya, Ali (dalam Al Mawardi (2013:78) berpendapat bahwa akhlak merupakan bagian yang membahas mengenai masalah baik dan buruknya sesuatu perilaku dengan ukuran wahyu atau Al-Qur'an dan hadits.

Beberapa penjelasan mengenai akhlak tersebut membawa pada sintesis bahwa akhlak merupakan suatu perwujudan budi pekerti dari seorang individu manusia yang terwujud dalam ucapan, perbuatan, dan tingkah lakunya yang memiliki sifat transcendental, dimana seluruh_bentuk tingkah lakunya tersebut berasal dari hati dan bukan dipengaruhi oleh akalnya sebagai manusia.

\section{Logika}

Adisubrata (dalam Kadir, 2015:389) yang menyebutkan bahwa logika berasal dari bahasa latin 'logos' yang artinya perkataan atau sabda. Pengertian ini juga dimaknai sebagai berkata atau berucap. Sedangkan menurut Kneller (dalam Kadir, 2015:390), logika didefinisikan sebagai penyelidikan tentang dasar-dasar dan metode berpikir secara benar (correct reason). Sedangkan Poespoprodjo (dalam Kadir, 2015:390) memberikan definisi bahwa logika menunjukkan, meletakkan, menguraikan, dan membuktikan hukum dan peraturan yang akan menjaga dan membatasi individu agar tidak terjerumus dalam kekeliruan. Idrus (2012:39) memaknai logika sebagai aspek-aspek pikiran yang melibatkan serangkaian proses mental untuk menciptakan suatu konsep dalam berpikir atau menalar (reasoning) secara logis. Kertayasa (2011:28-29) menjabarkan bahwa logika merupakan input bagi proses pemikiran manusia yang terbentuk dalam penalaran. Pengambilan keputusan dalam hidup yang tepat berdasar pada logika akan membantu individu dalam menemukan solusi yang dibutuhkan dalam setiap menghadapi masalah dengan menemukan kriteria kebenaran yang dibutuhkan (Aisyah, 2016:2).

Selanjutnya berdasar pada penjabaran di atas, ditarik sintesis dan bahwa logika adalah dasar berpikir, metode berpikir, dan hukum yang mengkaji mengenai kaidah berpikir untuk menguraikan, membuktikan, dan menentukan bentuk penalaran yang benar dan salah. 


\section{Kepemimpinan}

Hikmat (2014:249) mengartikan kepemimpinan sebagai suatu tugas dan kewajiban seseorang dalam memimpin. . Kepemimpinan juga harus memfasilitasi upaya-upaya yang dilakukan secara indovidu maupun kolektif sehingga tujuan bersama dapat tercapai (Yukl dalam Machali, 2016:84). Machali (2016:84) menjelaskan bahwa kepemimpinan atau leadership merupakan kemampuan untuk bersikap menggerakkan, mempengaruhi, memotivasi, mengajak, mengarahkan, menasehati, membina, membimbing, melatih, memerintah, melarang, dan bahkan menghukum seluruh sumber daya yang terdapat dalam organisasi.

Berdasarkan beberapa pendapat tersebut, maka dapat ditarik sintesis bahwa kepemimpinan merupakan suatu kemampuan yang melekat dalam diri setiap individu untuk mengarahkan, mengatur, mengendalikan, dan mengelola sistem organisasi atau lingkungan sekitar dimana individu itu berada untuk berinteraksi dalam mencapai suatu tujuan bersama. Dasar kepemimpinan ini adalah kemampuan untuk dapat mempengaruhi orang lain dan memberikan arahan kepada orang-orang di sekitarnya untuk dapat bekerjasama menjalankan roda organisasi sesuai dengan keinginan Bersama.

\section{Bisnis}

Sanusi (dalam Soryanto, 2010:5) bahwa bisnis merupakan suatu nilai yang diwujudkan ke dalam perilaku yang kemudian dijadikan sebagai sumber daya, tenaga penggerak, tujuan, strategi, kiat, proses, dan pada akhirnya menjadi hasil bisnis. Pengertian tentang bisnis diungkapkan oleh Bertens (dalam Norvadewi, 2015:33) yang menyebutkan bahwa bisnis merupakan kegiatan atau aktivitas ekonomis, dimana dalam kegiatan tersebut terjadi hal-hal seperti tukar-menukar, jual-beli, memproduksi dan memasarkan, bekerja-memperkerjakan, serta interaksi manusiawi lainnya yang bertujuan untuk memperoleh keuntungan.

Beberapa pengertian yang telah dijabarkan tersebut mengarahkan pada sintesis bahwa bisnis merupakan suatu bagian dari interaksi sosial yang terjadi dalam bentuk beragam dalam suatu masyarakat maupun organisasi yang lebih kecil. Terbentuknya bisnis ini memiliki tujuan untuk dapat memberikan dan menyediakan manfaat bagi seluruh komponen pembentuk yang ada di dalamnya. Pembentukan bisnis secara khusus berorientasi pada keuntungan, yang artinya seluruh bentuk kegiatan dan aktivitas yang terjadi dalam proses bisnis harus dapat saling menguntungkan, sehingga tidak berlaku asas untuk mencari keuntungan bagi satu pihak saja. Bisnis bertujuan untuk mensejahterakan seluruh komponen yang terlibat di dalamnya. Dengan demikian, tujuan dari suatu bentuk bisnis dapat dinyatakan berhasil dan tercapai apabila seluruh pihak dan komponen yang terlibat di dalamnya telah memperoleh dan merasakan keuntungan serta manfaat dari proses bisnis tersebut.

\section{METODE PENELITIAN}

Penelitian ini dilaksanakan di School of Universe pada jenjang Sekolah Dasar (SD) yang berlokasi di Jalan Raya Parung 314 Km. 43, Parung-Bogor, Jawa Barat. Waktu yang diperlukan untuk melaksanakan penelitian ini adalah sekitar empat bulan, yaitu sejak bulan Februari 2018 hingga bulan Mei 2018. Metode penelitian yang digunakan dalam penelitian ini adalah metode kualitatif deskriptif.

Fokus permasalahan yang diangkat dalam penelitian ini adalah bagaimana manajemen sekolah alam jenjang Sekolah Dasar di School of Universe dalam pengembangan akhlak, logika, kepemimpinan, dan bisnis di sekolah tersebut. Proses manajemen yang akan diteliti meliputi bagaimana tahapan perencanaan, pengorganisasian, pelaksanaan, monitoring dan evaluasi dalam penerapan pendidikan di sekolah alam tersebut. 


\section{HASIL PENELITIAN DAN PEMBAHASAN}

Temuan hasil penelitian terhadap empat sub fokus penelitian yang diperoleh melalui wawancara, observasi, dan studi dokumentasi kepada tujuh informan pada jenjang Sekolah Dasar School of Universe dijabarkan sebagai berikut.

Berdasarkan pengendalian yang telah dilakukan sebelumnya terhadap manajemen sekolah dalam pengembangan akhlak, logika, kepemimpinan, dan bisnis, maka disusun perencanaan program pendidikan sebagai berikut:

1. Tema dan konsep pendidikan di Sekolah Dasar School of Universe adalah sekolah alam yang bersifat tematik dengan metode belajar bersama alam (BBA). Konsep pendidikan di School of Universe mengacu kepada empat kurikulum pendidikan, yaitu kurikulum akhlak, logika, kepemimpinan, dan bisnis. Kurikulum akhlak menjadi kurikulum utama.

2. Sasaran dan tujuan pendidikan yang diterapkan pada Sekolah Dasar School of Universe dituangkan ke dalam visi sekolah yaitu untuk dapat membimbing manusia menjadi pemimpin yang amanah untuk dapat menjadi rahmat bagi sekalian alam.

3. Proses perencanaan program pendidikan menyesuaikan dengan keempat kurikulum dasar di School of Universe, yaitu kurikulum akhlak, logika, kepemimpinan, dan bisnis. Kemudian disusun tema untuk masing-masing kurikulum dan dijabarkan ke dalam program pendidikan yang dibagi ke dalam program pendidikan tahunan, program semester, program bulanan, program mingguan, dan program harian. berikut:

Berdasarkan perencanaan yang telah ditetapkan, maka disusun pegorganisasian sebagai

1. Struktur organisasi terdiri atas jabatan sesuai pembagian tugas dan fungsi yang dibutuhkan. Penetapan pengisi jabatan dalam struktur organisasi dituangkan ke dalam surat ketetapan (SK) dari yayasan. Struktur organisasi terdiri atas pimpinan yayasan (top management), manajemen (middle management), dan struktur organisasi tiap level.

2. Sumber daya utama dalam pengelolaan sekolah dan pendidikan di Sekolah Dasar School of Universe adalah sumber daya pembelajaran yang terdiri atas sumber daya manusia, sumber daya alam, metode, dan buku. Sedangkan sumber daya administratif terdiri atas sumber daya pengelola, teknologi, fasilitas sekolah, laboratorium, dan keuangan.

3. School of Universe tidak menerapkan secara khusus kriteria untuk menjadi peserta didik. Hal ini berdasarkan pada prinsip pendidikan untuk semua. Anak berkebutuhan khusus juga memiliki kesempatan untuk menempuh pendidikan di School of Universe, karena tersedia kelas inklusi dan juga fasilitas terapi. Bagi calon siswa disediakan program sit in atau trial, dimana calon siswa dapat terlebih dahulu mencoba mengikuti sistem pembelajaran di School of Universe. Sedangkan syarat untuk menjadi staf pengelola sekolah atau karyawan dan guru di School of Universe secara umum adalah Muslim dan memiliki kompetensi sesuai dengan kebutuhan bidang kerja pada jabatan masing-masing.

4. Metode dan pengelompokkan program dan kegiatan pendidikan di Sekolah Dasar School of Universe disusun ke dalam program plan oleh Kepala Sekolah berdasarkan masing-masing kurikulum akhlak, logika, kepemimpinan, dan bisnis. Kemudian disesuaikan dengan tema pada masing-masing kurikulum. Program kegiatan ada yang sifatnya wajib dan rutinitas serta dibagi berdasarkan kegiatan masing-masing level dan seluruh level. 
Berdasarkan pengorganisasian yang telah ditetapkan, maka disusun pengarahan dan pelaksanaan atau implementasi sebagai berikut:

1. Alur pendelegasian wewenang dimulai dari konseptor melalui Ketua Yayasan kemudian diteruskan ke manajemen yang terdiri dari Wakil Ketua Yayasan bidang Pendidikan yaitu Kepala Divisi School of Universe, Wakil Ketua Yayasan bidang personalia yaitu HRD, Wakil Ketua Yayasan bidang Operasional yaitu manajer sekolah, penelitian dan pengembangan (Litbang) atau Research and Development (R\&D), dan Kepala Divisi Maestro. Setelah itu, dari Kepala Divisi School of Universe diteruskan ke masing-masing level melalui Kepala Sekolah untuk dilanjutkan sampai pada staf dan guru.

2. Penerapan pendidikan sesuai dengan perencanaan yang telah disusun dan dengan pembagian tugas sesuai dengan fungsi yang telah ditetapkan. Pelaksanaan program pendidikan dijalankan berdasarkan program plan dan kalender kegiatan. Seluruh penyelenggaraan kegiatan mengacu pada Standard Operasional Procedure (SOP) yang telah ditetapkan oleh yayasan. Pengelolaan pendidikan juga disesuaikan dengan kebutuhan kurikulum dan dibimbing pelaksanaannya oleh tim dan konsultan.

3. Penyelenggaraan pendidikan di Sekolah Dasar School of Universe didukung dengan peraturan-peratura antara lain Piagam SoU yang mengatur proses penyelenggaraan pendidikan di School of Universe dan berlaku untuk semua warga sekolah pada semua level dan panduan bagi orangtua dalam bentuk handbook yang diberi nama Parents Guide Book yang dibagikan kepada orangtua siswa pada setiap awal tahun.

Berdasarkan pengarahan yang telah ditetapkan serta pelaksanaan yang dilakukan, maka disusun pengendalian sebagai berikut:

1. Monitoring dan evaluasi kegiatan dilakukan setiap pekan, bulan, dan pada akhir tahun dalam rapat kerja. Laporan evaluasi setiap bulan disusun dari catatan guru dan dilaporkan kepada Kepala Sekolah kemudian diteruskan ke pihak yayasan. Monitoring dan evaluasi ada yang berlaku untuk penilaian guru, siswa, dan program kegiatan pendidikan. Monitoring dan evaluasi untuk guru menggunakan format evaluasi diri sedangkan evaluasi untuk siswa menggunakan Ujian Akhir Semester (UAS) dan Ujian Nasional (UN). School of Universe tidak menerapkan sistem Ujian Tengah Semester (UTS) karena pola pembelajaran di School of Universe bersifat khas dan tidak sama dengan penerapan pembelajaran di sekolah umum. Penilaian siswa juga dibuat dalam penilaian deskriptif dan penilaian dalam bentuk nilai belajar.

2. Instrumen monitoring dan evaluasi yang digunakan antara lain format evaluasi diri guru untuk menilai kinerja guru, lembar catatan observasi siswa, soal ujian sekolah. Sekolah menyusun sendiri soal ujian karena menyesuaikan dengan penerapan pembelajaran yang berlangsung, sedangkan soal ujian dari Dinas digunakan sebagai bahan pengayaan.

3. Wewenang monitoring dan evaluasi terhadap guru dilakukan oleh Kepala Sekolah. Sedangkan monitoring dan evaluasi terhadap siswa dilakukan oleh guru. Monitoring dan evaluasi keseluruhan program dilakukan oleh yayasan melalui Kepala Bidang Akademik.

4. Mekanisme pelaporan hasil monitoring dan evaluasi untuk pelaksanaan program disusun oleh guru dan disampaikan dalam bentuk laporan tertulis kepada Kepala Sekolah. Bahan laporan dari guru tersebut disusun kembali oleh Kepala Sekolah untuk dijadikan laporan bulanan (monthly report) dan disampaikan ke pihak yayasan. Untuk pelaporan hasil monitoring dan evaluasi perkembangan siswa disajikan ke dalam bentuk rapor narasi pada pertengahan semester yang memberi penjelasan deskriptif mengenai perkembangan belajar siswa dan rapor nilai pada akhir semester 
yang merupakan laporan perolehan capaian belajar siswa dalam bentuk angka sesuai dengan format Dinas.

5. Faktor pendukung yang menunjang pelaksanaan program pendidikan yang sesuai dengan perencanaan, pengorganisasian, dan pengarahan yang telah dilakukan antara lain adanya fasilitas pembelajaran yang memadai yang tersedia di sekolah serta dukungan orangtua siswa dan Dinas Pendidikan. Kesamaan pola pendidikan yang diterapkan orangtua dengan pola pendidikan di sekolah akan menjadi pendorong pencapaian hasil pendidikan yang baik bagi siswa. Sedangkan yang menjadi faktor penghambat adalah ketidaksamaan persepsi dan pola pendidikan orangtua dengan pola pendidikan di sekolah.

Masing-masing tahapan dalam manajemen sekolah di Sekolah Dasar School of Universe memiliki keterikatan satu sama lain. Secara umum, sistem manajemen sekolah pada jenjang Sekolah Dasar di School of Universe sudah sangat baik dalam menunjang pencapaian tujuan dan prestasi yang telah ditargetkan dan direncanakan. Berdasarkan pembahasan tersebut, ditemukan beberapa hal pokok yang menjadi keunggulan dalam sistem manajemen sekolah di Sekolah Dasar School of Universe, diantaranya adalah:

1. Sistem kurikulum yang mengintegrasikan empat aspek pengembangan akhlak, logika, kepemimpinan, dan bisnis secara bersama dalam setiap pola pembelajaran menjadi nilai keunggulan tersendiri bagi Sekolah Dasar School of Universe.

2. Sistem manajemen telah ajeg dan berjalan secara konsisten namun dengan tetap bersifat fleksibel sesuai dengan perkembangan kebutuhan serta kondisi sekolah dan peserta didik, sehingga sistem bersifat luwes dan cenderung mudah untuk diadaptasi oleh pihak-pihak terkait.

3. Proses perencanaan, pengorganisasian, pengarahan dan pelaksanaan, serta pengendalian telah berjalan dengan teratur sesuai dengan pola dan arahan yang telah disepakati bersama oleh seluruh jajaran pengelola sekolah.

4. Pola pendidikan dengan mengedepankan pengembangan akhlak serta karakter siswa menjadi nilai tambah bagi School of Universe untuk meningkatkan daya saing dengan sekolah lain, karena pada dasarnya saat ini belum seluruh sekolah memiliki komitmen untuk mengutamakan pengembangan karakter dan akhlak anak dibandingkan hanya sekadar mementingkan pengembangan aspek kecerdasan atau logika saja.

5. Program pendidikan disusun ke dalam program berkala mulai dari program tahunan, semester, bulanan, pekanan, dan harian. Hal ini menjadi nilai tambah tersendiri bagi Sekolah Dasar School of Universe yang artinya mampu merencanakan program pendidikan mulai dari jangka panjang, menengah, dan pendek secara mendetail, terarah, dan berkesinambungan, sehingga pelaksanaannya dapat lebih terkendali sesuai perencanaan pada masing-masing program.

\section{SIMPULAN}

Berdasarkan hasil penelitian dan pembahasan, dapat disimpulkan bahwa seluruh tahapan manajemen sekolah mulai dari perencanaan, pengorganisasian, pengarahan dan pelaksanaan, serta pengendalian memegang peranan penting pada masing-masing tahapan. Oleh karena itu, keseluruhan proses tersebut perlu disusun secara baik, sistematis, dan terstruktur sesuai dengan konsep dasar dan berorientasi pada pencapaian optimal dalam pelaksanaan kurikulum akhlak, logika, kepemimpinan, dan bisnis di Sekolah Dasar School of Universe. 


\section{Perencanaan}

Kesimpulan yang diperoleh pada proses perencanaan sekolah dalam pengembangan akhlak, logika, kepemimpinan, dan bisnis adalah bahwa untuk menunjang keberhasilan dalam pencapaian prestasi siswa dan sekolah, diperlukan adanya perencanaan yang khas dan sesuai dengan konsep awal pendidikan di School of Universe. Perencanaan disusun berdasarkan kebutuhan yang sesuai dengan tema atau konsep pendidikan di School of Universe. Penyusunan perencanaan pendidikan mengacu kepada empat pilar pendidikan School of Universe yang kemudian dituangkan menjadi kurikulum akhlak, logika, kepemimpinan, dan bisnis.

\section{Pengorganisasian}

Pengorganisasian sekolah yang baik berdasarkan perencanaan yang telah disusun dalam pengembangan akhlak, logika, kepemimpinan, dan bisnis menunjang pencapaian prestasi sekolah dan siswa. Pengorganisasian kegiatan pendidikan dikelompokkan berdasarkan empat kurikulum dasar, masing-masing kurikulum memiliki muatan kegiatan yang berbeda-beda.

\section{Pengarahan dan Pelaksanaan}

Pengarahan dan pelaksanaan berdasarkan pada tahapan perencaaan dan pengorganisasian yang telah ditetapkan di awal. Pengarahan dilaksanakan sesuai dengan alur pendelegasian yang telah ditentukan serta diatur dalam Piagam SoU yang menjadi acuan peraturan dalam pelaksanaan seluruh kegiatan pendidikan di sekolah yang berlaku untuk seluruh warga sekolah. Pelaksanaan program pendidikan menyesuaikan dengan perencanaan yang telah dituangkan dalam program plan dan kalender kegiatan yang disesuaikan dengan penanggungjawab berdasarkan pengorganisasian yang telah dilakukan. Setelah itu akan diterapkan sesuai dengan Standard Operasional Procedure (SOP). Pelaksanaan program pendidikan juga akan dibimbing oleh tim penyusun dan konsultan masing-masing kurikulum.

\section{Pengendalian}

Tahap akhir setelah perencanaan, pengorganisasian, dan pengarahan untuk menunjang pencapaian prestasi sekolah dan siswa di Sekolah Dasar School of Universe adalah dengan pengendalian melalui monitoring dan evaluasi. Monitoring dan evaluasi program dan kegiatan dilaksanakan setiap pekan, bulan, dan tahunan. Monitoring dan evaluasi dilakukan oleh Yayasan dan Kepala Sekolah terhadap guru dan program pendidikan yang berlangsung. Sedangkan monitoring dan evaluasi terhadap siswa dilakukan oleh guru dengan mekanisme catatan perkembangan siswa dan ujian. Instrumen yang digunakan dalam melaksanakan monitoring dan evaluasi terhadap guru dan program pendidikan menggunakan format evaluasi diri, catatan observasi Kepala Sekolah dan yayasan. Sedangkan untuk melakukan monitoring dan evaluasi terhadap siswa menggunakan instrumen lembar catatan narasi observasi perkembangan siswa dan soal ujian sekolah yang disusun sendiri oleh sekolah.

\section{DAFTAR PUSTAKA}

Ballantyne, Roy., dan Packer, Jan. 2008. Learning for Sustainability: The Role and Impact of Outdoor and Environmental Education Centres. Australia: The University of Queensland.

Connie Chairunnisa. 2016. Manajemen Pendidikan dalam Multi Perspektif. Depok: PT. Rajagrafindo Persada.

Erickson, Martha Farrell. 2008. Ensuring That All Children Can Spend Quality Time Outdoors. Beyond the Journal: The Children \& Nature Network. 
Heri Maulana. 2016. Pelaksanaan Pendidikan Karakter di Sekolah Alam. Jurnal Khasanah Ilmu. Volume 7, No.1 : 21-31.

Hikmat. 2014. Manajemen Pendidikan. Bandung: CV. Pustaka Setia.

Imam Machali. 2016. The Handbook of Education Management. Jakarta: Prenadamedia Group.

Kadir Sobur. 2015. Logika dan Penalaran dalam Perspektif Ilmu Pengetahuan. Jurnal Tajdid. Volume XIV, No.2 : 387-414.

Lloyd, Amanda., dan Gray, Tonia. 2014. Place-Based Outdoor Learning and Environmental Sustainability within Australian Primary Schools. Journal of Sustainability Education. [Online]. Tersedia: http://www.susted.org/. [diakses tanggal 4 Agustus 2017].

Norvadewi. 2015. Bisnis dalam Perspektif Islam. Jurnal Ekonomi dan Bisnis Islam Al-Tijary. Volume 1, No.1 : 33-46.

Nurochim. 2016. Administrasi Pendidikan. Bekasi: Gramata Publishing.

Rasyad. 2015. Dimensi Akhlak dalam Filsafat Islam. Jurnal Substantia. Volume 17, No.1 : 89-102.

Rosenow, Nancy. 2008. Learning to Love the Earth and Each Other. Beyond the Journal: Teaching and Learning abaout the Natural World. [Online]. Tersedia: http://www.journal.naeyc.org/. [diakses tanggal 4 Agustus 2017].

Tatang S. 2015. Manajemen Pendidikan Berbasis Sekolah. Bandung: CV. Pustaka Setia.

Wilson, Carla. 2011. Effective Approaches to Connect Children with Nature. New Zealand: Department of Conservation. 